\title{
Molecular Cloning, Over-expression, Kinetic and Structural Properties of Purified Recombinant Family VII Carboxyl esterases
}

\author{
T. Ndiitwani, KJ. Rashamuse, SW. Limani, MB. Nthangeni, MG. Tlou
}

\begin{abstract}
Carboxyl esterases (EC 3.1.1.1) are $\alpha / \beta$ hydrolases which act on acylglycerols to liberate fatty acids and glycerol. They are amongst the most sort-after biocatalysts due to the potential for application in various industries i.e. food, dairy, pharmaceutical, detergents, textile, biodiesel, and cosmetic industries, a factor that drives the continued identification and kinetic characterization for these enzymes. The carboxyl esterase (CEST) genes from Geobacillus kaustophilus (Est179), B. licheniformis (Est96) and B. pumilus (Est95) were expressed in Escherichia coli. For the purified CESTs, temperature optima assays showed that Est95 and 96 were optimally active at $45^{\circ} \mathrm{C}$ while the optimum activity for Est 179 was recorded between $45^{\circ} \mathrm{C}$ and $55^{\circ} \mathrm{C}$. Furthermore, Est95 and 96 retained more than $95 \%$ of activity at temperature ranges between $25-40^{\circ} \mathrm{C}$ while, Est179 retained about $80-100 \%$ activity between $25-60{ }^{\circ} \mathrm{C}$. The CESTS were also subjected to substrate specificity assays which revealed that the enzymes showed high affinity for $p$-nitrophenyl butyrate ( $\rho \mathrm{NP}-\mathrm{C} 4)$ as demonstrated by the low $\mathrm{K}_{\mathrm{m}}$ obtained in comparison to other test substrates. However, the ratio for the specificity constants $\left(\mathrm{k}_{\text {cat }} / \mathrm{K}_{\mathrm{M}}\right)$ revealed $\rho \mathrm{NP}-\mathrm{C} 3$ (propionate) was a preferred substrate for Est 95 , while $\rho \mathrm{NP}-\mathrm{C} 2$ (acetate) and $\rho \mathrm{NP}-\mathrm{C} 4$ were preferred substrates for Est96 and Est179, respectively. Circular Dichroism (CD) spectroscopy-assisted secondary structure predictions recorded spectra that were consistent with a $\alpha$-helical content for all three proteins. Intrinsic fluorescence spectroscopy-based comparative analysis of protein tertiary structure revealed a difference in the conformation for the 3 proteins, a possible explanation for the differences in the kinetic properties. Therefore, this study constitutes a report on three family VII CESTs that are optimally active at near-neutral to alkaline $\mathrm{pH}(6.5-9)$, mesotable to moderately thermostable and with a preference for short-chain acyl esters. The outcomes of this study forms the basis for future experiments aimed at evaluating CESTs properties for potential application in specific industries.
\end{abstract}

Keyword: Bacillus species, Family VII Carboxyl esterases, enzyme kinetics, intrinsic fluorescent and Circular Dichroism Spectroscopy.

\section{INTRODUCTION}

Lipolytic enzymes are carboxylic ester hydrolases which act on acylglycerols to liberate fatty acids and glycerol. These enzymes have been grouped into two major classes based on substrate specificity, carboxyl esterases (3.1.1.1.) and lipases (EC 3.1.1.3), which respectively hydrolyse esters of short-chain

Manuscript received October 10, 2019.

T. Ndiitwani and MG. Tlou: Department of Biochemistry, School of Physical and Chemical Sciences, Faculty of Natural and Agricultural Sciences, North-West University, Mafikeng Campus, MMabatho 2790, South Africa

KJ. Rashamuse: Council for Scientific and Industrial Research, Biosciences, P.O. Box 395, Pretoria, 0001, South Africa

SW. Limani and MB. Nthangeni:Onderstepoort Biological Products, Old Soutpan Road, Onderstepoort, Pretoria 0001, South Africa. carboxylic acids $(\mathrm{C}<10)$ and maximally active towards water insoluble long chain substrates $(\mathrm{C} \geq 10)[1,2]$. Although lipolytic enzymes have been found in many species of animals, plants, bacteria, yeast and fungi, the enzymes from microorganisms have attracted considerable attention because of their potential applications in various industries such as food, dairy, pharmaceutical, detergents, textile, biodiesel, and cosmetic industries [3].

Since the classification of bacterial lipolytic enzymes into 8 families by Arpigny and co-workers [4], more enzymes have been identified and the classification recently updated to 19 families [2]. The choice enzymes for this study are classified under the Family VII, which is characterized by enzymes that are relatively large in size $(\sim 55 \mathrm{kDa})$ which shared significant homology (30\% identity, $40 \%$ similarity) with eukaryotic acetylcholine esterases and mammalian CESTs. This family was previously reported to be comprising of a few enzyme by Arpigny and co-workers [4] and since then, more than a 100 putative Family VII bacterial CEST could be revealed through analyses of nucleotide sequences deposited in nucleotide databases. Most of the putative Family VII gene sequences are discovered as part of genome DNA sequences of microorganisms from extreme environments, organisms that are deemed to be of industrial importance or that have health related concerns. The proteins showing significant similarity (more than 30\% amino acid sequence identity) with the reference Family VII Arthrobacter oxydans CEST include proteins identified in Salmonella, Mycobacteriaceae, Bacillaceae, Streptosporangium, Thermomonospora, Thermobifida and Desulfitobacterium species.

To date, there are relatively few reports on the expression and biochemical characterization of these enzymes which suggests that the biotechnological potential is underexplored. The biotechnological potential for this group enzymes is supported by the identification of Family VII CESTs that are active at elevated temperatures [5], catalyze the entatioselective resolution of racemic drug intermediates [6], biodegradation of the pesticide, carbamate [2] and various other properties [7;8]. This therefore, necessitates studies aimed at investigating the various reactions that are characteristic to this family of enzyme and a comparison of function to protein structure.

The three dimensional structures of p-nitrobenzyl esterase from B. subtilis [9], and G. stearothemophilus [10] which are members of Family VII lipolytic proteins have been determined. The structural analyses of proteins revealed that the proteins belong to the alpha/beta hydrolase family [11]. The proteins contain a catalytic triad composed of Ser, His and Glu and as with the mammalian CEST they fold into three structural 
domains, a catalytic domain, an alpha/beta domain and a regulatory domain [10]. The availability of the three dimensional structure of $G$. stearothermophilus CEST has enabled molecular dynamics simulation studies to identify thermostable and thermosensitive regions of this member of Family VII lipolytic protein [12]. However, the availability of technologies such as Far-UV Circular Dichroism (CD) [13] and Intrinsic Fluorescence Spectroscopy [14], respectively allow for the preliminary analysis of protein secondary and tertiary structure which can complement the intricacies of protein molecular modelling and simulations.

We therefore, report in this study the utility of gene codon adaptation in the expression of a putative CEST belonging to Family VII lipolytic proteins identified within the thermophilic G. kaustophilus genome, the expression of mesophilic CEST derived from $B$. licheniformis and $B$. pumilus and the biochemical properties of the three enzymes. We also report on the Intrinsic Flourescence and Circular Dichroism spectroscopy - based comparative analysis of the secondary and tertiary structures for the proteins. The findings reported in this study will form the basis for future application-based investigations for this family of enzymes.

\section{MATERIALS AND METHODS}

\section{A. Dna Manipulations, Bacterial Strains, And Culture Conditions}

Bacillus pumilus MBB02 [15], B. licheniformis DSM12369 and G. kaustophilus HTA426 (obtainable from the Japanese Collection of Cultures) were used. Escherichia coli JM109 and E. coli JM109 DE3 host and expression cells were purchased from Promega (Madison, USA). The expression plasmid pET28a was obtained from Novagen. The bacterial strains were grown in Luria Bertani (LB) media [20] at $37{ }^{\circ} \mathrm{C}$ with shaking in $5 \mathrm{ml}, 50 \mathrm{ml}$ or $250 \mathrm{ml}$ shake flasks. $\mathrm{CaCl}_{2}$ competent $E$. coli cells were prepared and transformed with DNA as described by [16].

\section{Dna Techniques}

Standard microbial and recombinant techniques using commercially available molecular biology grade enzymes were as described by [16]. Oligonucleotide primers were purchased from Intergrated DNA Technologies (USA). The DNA fragments for subcloning and plasmid DNA (pGemT-easy and pET28a) were recovered and purified GFX PCR and Gel band purification kit and Biospin Plasmid DNA extraction kit, respectively. Sequencing was done at Inqaba using the T7 and Sp6 promoter primers. The nucleotide sequences were translated to amino acid sequences and analysed using the Expasy Proteomics tools (http://www.expasy.ch).

\section{B. Cloning Of Carboxyl Esterase Genes}

The genomic DNA sample B. licheniformis and B. pumilus was used as the template using the forward and reverse primer pairs indicted in supplementary Table 1 . The PCR was done according to standard conditions using Expand DNA polymerase (Roche).

The open reading frame encoding the CEST gene from $G$. kaustophilus was also codon optimized for expression in E. coli and synthesized by GeneArt (Germany). The sequence of the
G. kautophilus was optimized for codon adaptation in E. coli. The gene was re-synthesized chemically (GeneArt, Germany) and subcloned into pUC18 to create pGA-Gk-CEST. The re-synthesized gene contained the $N c o$ I and XhoI restriction sites on the 5 and 3 prime ends, respectively. The incorporation of the restriction sites, as can also be seen in supplementary Table 1, is to facilitate directional cloning into expression vector pET28a.

\section{Expression Of Carboxyl Esterases}

The CEST genes were released from pGemT-Easy/pGA-Gk-Cest vector using NcoI and SalI and ligated to pET28a digested with NcoI and Xhol to create plasmids denoted MBE179, MBE95 and MBE96 corresponding to $\mathrm{pET} 28 \mathrm{a}$ vector carrying carboxyl esterase CEST genes from G. kaustophilus, B. licheniformis and B. pumilus, respectively. All the plasmids were transformed into E. coli JM109 (DE3) cells and a single colony (from each transformation) containing the plasmid was grown in $50 \mathrm{ml} \mathrm{LB}$ containing kanamycin to anabsorbance of approximately 0.8 at $600 \mathrm{~nm}$. The culture was then adjusted to $0.5 \mathrm{mM}$ IPTG, and incubation continued at $30{ }^{\circ} \mathrm{C}$ for $10 \mathrm{~h}$. Cells were harvested by centrifugation at $5000 \mathrm{X} \mathrm{g}$ for $10 \mathrm{~min}$, resuspended and Incubated in $10 \mathrm{mM}$ phosphate buffer, $\mathrm{pH} 8.0$ containing $1 \mathrm{mg} / \mathrm{ml}$ lysozyme for $30 \mathrm{~min}$, followed by sonification with a Branson Sonifier Cell Disrupter to release intracellular proteins. The cell-free extract was centrifuged at $10000 \mathrm{~g}$ for $20 \mathrm{~min}$ to remove cell debris, and assayed for carboxyl esteraseCEST activity. Fractions containing intracellular and extracellular lipase activity were combined, lyophilized and stored at $-20{ }^{\circ} \mathrm{C}$.

\section{Purification Of Recombinant Carboxyl Esterase Genes}

Following lypholization crude enzyme extracts were dissolved in $50 \mathrm{ml}$ of Na-phosphate buffer (20 mM, pH 7.4) and were loaded onto a HisPrep ${ }^{\text {TM }}$ 16/10 IMAC Ni-Sepharose 6 Fast Flow column (Amersham Biosciences) pre-equilibrated with Na-phosphate buffer (20 mM, pH 7.4) containing $0.3 \mathrm{M}$ $\mathrm{NaCl}$ and $20 \mathrm{mM}$ Imidazole.(Wash buffer). Unbound proteins were washed with 5 column volumes of wash buffer. Proteins bound to Ni-Sepharose matrix were eluted over 5 column volumes at a flow rate of $5 \mathrm{ml} \mathrm{min}{ }^{-1}$ with a one-step gradient of $0.5 \mathrm{M}$ imadazole generated with Na-phosphate buffer $(20 \mathrm{mM}$, $\mathrm{pH} 7.4$ ) containing $0.3 \mathrm{M} \mathrm{NaCl}$ and $0.5 \mathrm{M}$ Imidazole. Fractions $(5 \mathrm{ml})$ were collected and the imidazole was removed by dialysis and fractions exhibiting activity were pooled, concentrated (Centriprep YM-10, cut-off, $10 \mathrm{kDa}$, Millipore) before analysed on the SDS-PAGE.

\section{E. Protein And Enzyme Activity Assays}

For routine enzyme assay, esterase activity was determined as essentially described by [17]. Protein concentrations were determined by the method of [18], using bovine serum albumin (BSA, Sigma-Aldrich) as a standard. Denaturing sodium dodecyl sulphate polyacrylamide gel electrophoresis (SDS-PAGE) was carried out according to the method of [19].

\section{Effect Of Ph And Temperature}


Thermostability of the purified esterases was determined over the temperature range of $25-90{ }^{\circ} \mathrm{C}$. Enzyme samples were incubated for $10 \mathrm{~min}$ at various temperature ranges in Tris- $\mathrm{HCl}$ $(50 \mathrm{mM} . \mathrm{pH} 7.5)$ and the residual activity determined using standard assay.

\section{Kinetic Constants}

Experimental data of initial velocity versus substrate concentration with coefficients of variation of $<5 \%$ were fitted to the Michaelis-Menten equation by weighted nonlinear regression (Hyperbola) analysis using GraphPad Prism version 5.0.

\section{F. Far-Uv Cd And Intrinsic Spectroscopy}

Far-ultraviolet circular dichroism (far-UV CD) spectra were measured between 250 and $180 \mathrm{~nm}$ in $2 \mathrm{~mm}$ quarts cuvette at $25^{\circ} \mathrm{C}$ using a Jasco J-500 spectrophotometer (Jasco, China) equipped with a temperature control system. The CD spectra are an average of 15 accumulations, using the scan speed of 100 $\mathrm{nm} / \mathrm{min}, 1 \mathrm{~nm}$ bandwidth, $0.5 \mathrm{~nm}$ data pitches were applied, with response time of $1 \mathrm{~s}$. The concentration of hybrid and parental CESTs was $5 \mu \mathrm{M}$ in $10 \mathrm{mM}$ sodium phosphate buffer, $\mathrm{pH}$ 7.4. The spectra were buffer corrected and converted to mean residue ellipticity $[\theta]$ using the following equation: $[\theta]=$ $(100 \theta) /(\mathrm{cnl})[\theta]$ is the molar ellipticity (degrees square centimetre perdecimole), $\theta$ is ellipticity (millidegrees), $\mathrm{c}$ is the protein concentration (millimolar), $\mathrm{n}$ is the number of residues in the peptide, and 1 is the path length (centimetres). Analysis of secondary structural content of CESTs was performed using the online web server DichroWeb (http://www.cryst.bbk.ac.uk/cdweb).

Fluorescence spectrophotometer was used to assess localized conformational changes in the tertiary structure of enzymes. The Trp and Tyr residues were both excited at 280 $\mathrm{nm}$. Emission spectra were measured between 290 and $450 \mathrm{~nm}$ using a Jasco FP-6300 spectrophotometer (Jasco, china) at 20 ${ }^{\circ} \mathrm{C}$. The scan speed of $100 \mathrm{~nm} / \mathrm{min}$ and emission bandwidth of $2.5 \mathrm{~nm}$ were used. Excitation and emission slits were both set at $2.5 \mathrm{~nm}$. The assays were carried out in $1 \mathrm{~cm}$ sealed cell using 5 $\mu \mathrm{M}$ of each protein in $10 \mathrm{mM}$ sodium phosphate buffer, $\mathrm{pH}$ 7.4. The spectra are an average of three accumulations.

\section{RESULTS}

\section{A. Carboxyl Esterase Genes Cloning And Optimisation}

The DNA sequences containing open reading frames encoding functional CEST genes from $B$. pumilus and $B$. licheniformis have been described previously [15] while the gene encoding the putative CEST gene from G. kaustophilus has been revealed as part of the whole genome sequencing of the organism [20]. The PCR techniques used to amplify the ORFs were successful ( $\sim 1.5 \mathrm{~kb}$ was amplified) and nucleotide sequences were verified by sequencing (data not shown).

The gene encoding the CEST from G. kaustophilus was also subjected to optimization using GeneOptimizer ${ }^{\mathrm{TM}}$ (Geneart $\mathrm{GmbH}$, Regensburg). This included codon usage adaptation for optimal for expression in E. coli, which was also a success (data not shown). These 3 genes encoded proteins of 489,484 and 499 amino acid residues, respectively corresponding to lengths.

\section{B. Over-Expression Of Carboxyl Esterases And Purification}

The pMBE95, pMBE96, and pMBE179 are pET28a derived expression vectors respectively carrying $B$. pumilus, $B$. licheniformis, G. kaustophilus and synthetic codon optimized G. kaustophilus CEST structural genes. The constructs placed the CEST ORFs in frame for expression under the T7 promoter of the pET28a expression vector and in-frame with the vector's sequence coding for 6X histidine residues. E. coli JM 109 (DE3) was used as the expression host and the transformed cells were grown to nearly stationary phase followed by induction of gene expression using IPTG. Fractionation studies revealed significant esterase activity in both the extracellular and intracellular soluble fractions (Supplementary Table II). Based on these observations, cultures expressing recombinant esterases were freeze-dried in order to retain the total activities from both fractions. The CEST activities from E. coli DE3 strains pMBE95, pMBE96, and pMBE179 were denoted as Est95, Est96 and Est179, respectively indicating CESTs from B. pumilus, B. licheniformis and G. kaustophilus.

The lyophilized CEST fractions were purified to near homogeneity in one step purification using HisPrep ${ }^{\mathrm{TM}} 16 / 10$ IMAC Ni-Sepharose 6 Fast Flow column (Fig. 1). The molecular size of the purified CESTs was found to be about 54 $\mathrm{kDa}$ on SDS-PAGE (Fig. 1), in agreement with the estimated molecular mass from the translated nucleotide sequences. The purified CESTs had the following specific activities against $\rho$-nitrophenyl acetate; Est95 $=12.7 \mathrm{U} \cdot \mathrm{mg}^{-1}$, Est96 $=35.4$ U.mg ${ }^{-1}$ and Est179 = $\left.49.4 \mathrm{U}_{\mathrm{mg}}{ }^{-1}\right)$ (Supplementary Table II).

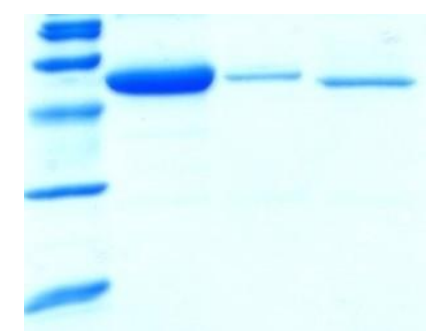

Fig. 1 SDS-PAGE analyses of Est95 (lanes 2), Est96 (lanes 3) and Est179 (lanes 4).

\section{Biochemical Characterisation Of Recombinant Carboxyl Esterases}

The activities of Est95, Est96 and Est 179 were examined as a function of temperature. The Est95 and EstE96 CESTs of CEST from B. pumilus, B. licheniformis and G. kaustophilus, giving proteins with theoretical molecular masses of about 54 $\mathrm{kDa}$. The predicted $\mathrm{pI}$ values of the proteins were 4.86, 5.38, and 5.7 corresponding to CEST from $B$. pumilus, $B$. licheniformis and G. kaustophilus, respectively. The deduced amino acid sequences showed at least $29 \%$ identity with the sequence of A. oxydans CEST, the reference Family VII lipolytic enzyme [4]. The conserved GESAG motif which contains the catalytic Ser residue could be identified within the sequences of the three proteins [15]. Showed optimal activities at $45^{\circ} \mathrm{C}$ while Est 179 had optimum activity between $45^{\circ} \mathrm{C}$ and $55^{\circ} \mathrm{C}$. The thermostabilities of the three recombinant esterases were calculated as a percentage of the initial activity remaining 
after 10 min incubation at a temperature range of 20 to $70^{\circ} \mathrm{C}$ (Fig. 2). Est95 and Est96 retained more than $95 \%$ of activity at temperature range between $25-40{ }^{\circ} \mathrm{C}$. At more elevated temperatures (above $40{ }^{\circ} \mathrm{C}$ ) more than $60 \%$ of initial activity was lost for both enzymes. However, Est179 retained

\begin{tabular}{|c|c|c|c|c|c|}
\hline Enzyme & Substrate & $\begin{array}{l}\mathbf{K}_{\mathrm{m}} \\
(\mathbf{m M})\end{array}$ & $\begin{array}{l}V_{\text {max }} \\
\left(\text { U.mg }^{-1}\right)\end{array}$ & $\begin{array}{l}\mathbf{K}_{\text {cat }} \\
\left(\mathrm{s}^{-1}\right)\end{array}$ & $\begin{array}{l}\mathbf{K}_{\mathrm{cat}} / \mathbf{K}_{\mathrm{m}} \\
\left(\mathrm{s}^{-1} / \mathbf{m M}\right)\end{array}$ \\
\hline \multirow{3}{*}{ Est95 } & $\begin{array}{l}\text { Acetate, } \\
\text { p-NP-C2 }\end{array}$ & $\begin{array}{l}177.3 \pm \\
27.9\end{array}$ & $\begin{array}{l}3096 \pm 30 \\
9.6\end{array}$ & $\begin{array}{l}5356 \pm \\
79.4\end{array}$ & 30.26 \\
\hline & $\begin{array}{l}\text { Propionat } \\
\text { e, } \\
\text { p-NP-C3 }\end{array}$ & $\begin{array}{l}4.61 \pm 1 \\
.30\end{array}$ & $\begin{array}{l}327.3 \pm 49 \\
.84\end{array}$ & $\begin{array}{l}566 \pm 8 \\
6.19\end{array}$ & 123.04 \\
\hline & $\begin{array}{l}\text { Butyrate, } \\
\text { p-NP-C4 }\end{array}$ & $\begin{array}{l}4.24 \pm 2 \\
.51\end{array}$ & $\begin{array}{l}345.1 \pm 99 \\
.85\end{array}$ & $\begin{array}{l}35.6 \pm 1 \\
0.27\end{array}$ & 8.39 \\
\hline \multirow{3}{*}{ Est96 } & $\begin{array}{l}\text { Acetate, } \\
\text { p-NP-C2 }\end{array}$ & $\begin{array}{l}112.4 \pm \\
90.49\end{array}$ & $\begin{array}{l}2022 \pm 14 \\
8.5\end{array}$ & $\begin{array}{l}3199 \pm \\
235.0\end{array}$ & 28.46 \\
\hline & $\begin{array}{l}\text { Propionat } \\
\text { e, } \\
\text { p-NP-C3 }\end{array}$ & $\begin{array}{l}27.2 \pm 2 \\
.5\end{array}$ & $176 \pm 11.8$ & $\begin{array}{l}278.5 \pm \\
18.7\end{array}$ & 10.23 \\
\hline & $\begin{array}{l}\text { Butyrate, } \\
\text { p-NP-C4 }\end{array}$ & $\begin{array}{l}23.0 \pm 5 \\
.9 \\
\end{array}$ & $129 \pm 23.4$ & $\begin{array}{l}205.4 \pm \\
37.1 \\
\end{array}$ & 9.10 \\
\hline \multirow{3}{*}{ Est179 } & $\begin{array}{l}\text { Acetate, } \\
\text { p-NP-C2 }\end{array}$ & $\begin{array}{l}32.5 \pm 1 \\
9.3\end{array}$ & $\begin{array}{l}2469 \pm 11 \\
5.1\end{array}$ & $\begin{array}{l}9040 \pm \\
421.6\end{array}$ & 282.5 \\
\hline & $\begin{array}{l}\text { Propionat } \\
\text { e, } \\
\text { p-NP-C3 }\end{array}$ & $\begin{array}{l}22.8 \pm 5 \\
.4\end{array}$ & $\begin{array}{l}1252 \pm 22 . \\
3\end{array}$ & $\begin{array}{l}4586 \pm \\
818.0\end{array}$ & 201.14 \\
\hline & $\begin{array}{l}\text { Butyrate, } \\
\text { p-NP-C4 }\end{array}$ & $\begin{array}{l}4.8 \pm 0 . \\
9\end{array}$ & $\begin{array}{l}678.2 \pm 67 \\
.50\end{array}$ & $\begin{array}{l}2483 \pm \\
24.7\end{array}$ & 517.28 \\
\hline
\end{tabular}

significant activity (80-100\%) between $25-60{ }^{\circ} \mathrm{C}$. Significant Est179 activity $(>70 \%)$ was lost at temperature above $70{ }^{\circ} \mathrm{C}$. The purified recombinant CESTs displayed optimal catalytic activity at the following $\mathrm{pH}$ ranges 7-8, 7-9, 7.5-9 for Est95, Est96 and Est179 CESTs, respectively (Fig. 3).

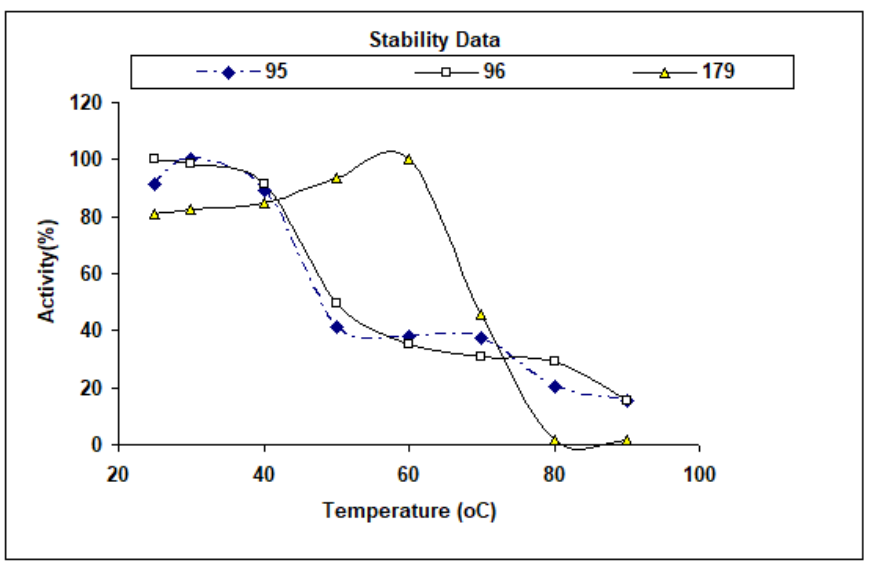

Fig. 2 Temperature stability profiles of purified Est95, Est96, and Est179 esterases. The enzymes were incubated for $10 \mathrm{~min}$ at various temperatures and the residual activity was measured under the standard reaction conditions.

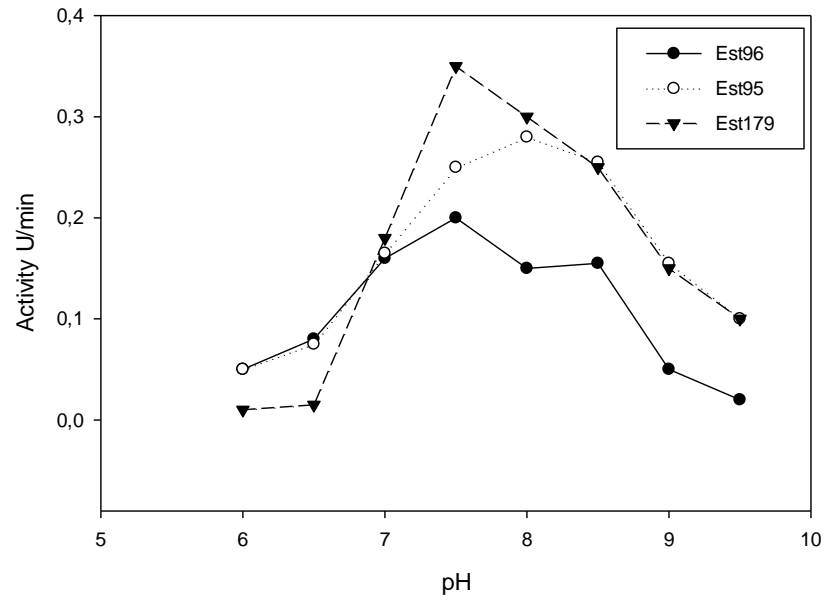

Fig. 3 pH optima profiles Est95, Est96 and Est179 esterases. The activity was assayed in buffers with different $\mathrm{pH}$ values.

\section{Kinetic Studies}

The substrate specificities of the three purified esterases against different fatty acyl chain length were determined using $\rho$-nitrophenyl esters of C2-C16. Substrate selectivity of the three enzymes were highest against shorter acyl chain lengths (C2-C4) (data not shown). Using three readily hydrolysed $\rho$-nitrophenyl ester substrates (C2, C3 and C4), kinetic constants for the three enzymes were calculated (Table I) using the Michaelis-Menten non-linear regression hyperbola. All three enzymes showed high affinity for $\rho \mathrm{NP}-\mathrm{C} 4$ as demonstrated by the low $\mathrm{K}_{\mathrm{m}}$ obtained in comparison with the result obtained for pNP-C2 and pNP-C3 substrates. Specificity constants $\left(\mathrm{kcat} / \mathrm{K}_{\mathrm{m}}\right)$ ratios revealed $\rho \mathrm{NP}-\mathrm{C} 3$ was a preferred substrate for Est95, while $\rho \mathrm{NP}-\mathrm{C} 2$ and $\rho \mathrm{NP}-\mathrm{C} 4$ were preferred substrates for Est96 and Est179, respectively.

$$
\text { TABLE I }
$$

\section{COMPARATIVE KINETIC PROPERTIES OF EST95, EST96 AND EST179}

\section{E. Far-Uv Cd And Intrinsic Fluorescence Spectroscopy}

The CD spectra were measured in the wavelength range of 250 and $180 \mathrm{~nm}$. The far-UV CD spectra for the three CESTs showed a double negative minimum around 210 and $220 \mathrm{~nm}$ with crossover positive maxima around $192 \mathrm{~nm}$ (Fig. 4A) which is consistent with a secondary structure consisting of $\alpha$-helices and $\beta$-sheets [21, 22 and 23], a characteristic feature for $\alpha / \beta$ class proteins [24]. The intrinsic tryptophan fluorescence assay was used to assess the localized conformational changes in the tertiary structures of esterases. All esterases possess fluorophores residues (tryptophan and tyrosine residues). Therefore, tryptophan (Trp) residues were used as the reporter for local tertiary structure differences. Tyrosine and tryptophan residues were excited at $280 \mathrm{~nm}$ wavelength in order to detect the contribution of both residues in global conformation of the tertiary structure. All esterases had their maximum fluorescence intensities close to $350 \mathrm{~nm}$ (fig. 4B). Est95 and Est96 had the fluorescence intensity of 25 and 20 (arbitrary units) respectively whereas Est179 displayed the highest fluorescence intensity 38 arbitrary units. 

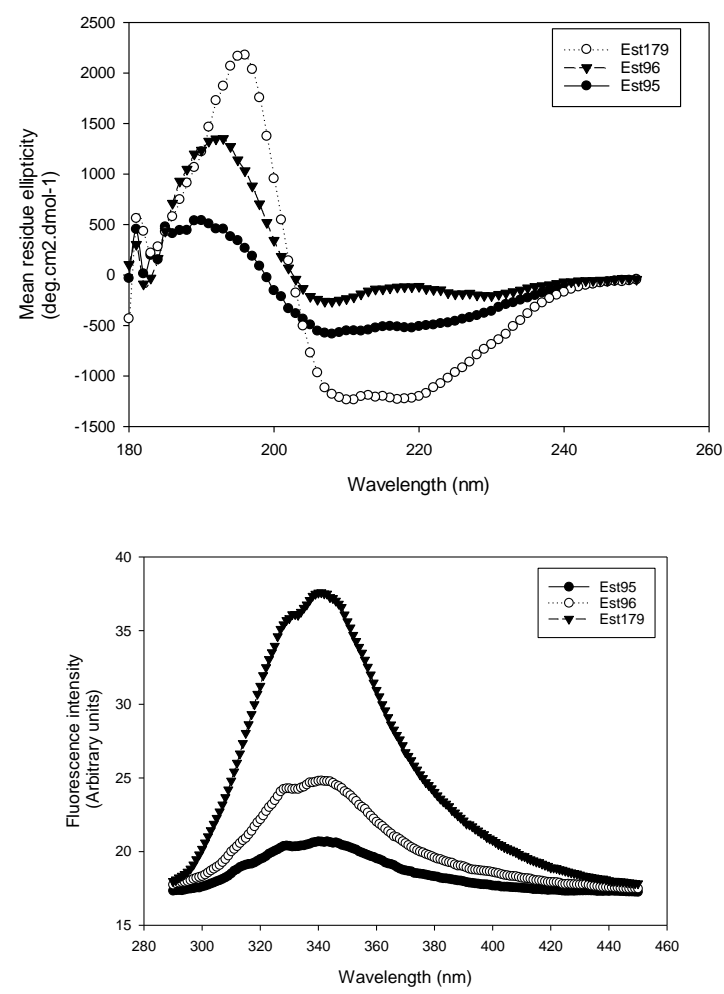

Fig. 4 Far-UV circular dichroism spectra on $5 \mu \mathrm{M}$ of CEST from bacillus species (A). Fluorescence spectra on $5 \mu \mathrm{M}$ of CEST from bacillus species $(\mathrm{B})$.

\section{DISCUSSION}

There are more than 100 gene sequences in nucleotide databases sharing $35 \%$ or more identity with the classical Family VII CEST gene derived from Arthrobacter oxydans. To date, only a few number of Family VII lipolytic enzymes have been expressed and characterized biochemically. It is not clear why there is a huge gap in the number of Family VII gene sequences published to date and the number of genes that have been expressed and characterized biochemically. It is significant that the catalytic activities of Family VII lipolytic proteins be elucidated as this will enable full biotechnological exploitation and understanding of structure function relationships. In this study we described the cloning, expression and characterization of three Family VII CESTs from mesophilic Bacillus pumilus and B. licheniformis species, and from a moderate thermophile, G. kaustophilus. Although genes encoding CEST from Bacillus licheniformis, B. pumilus and G. kaustophilus have been reported in nucleotide databases, their expression and biochemical characterizations has not yet been reported.

The CESTs from mesophilic B. pumilus and B. licheniformis could be readily expressed in $E$. coli DE3 cells. The expression of the CEST from G. kaustophilus, a moderate thermophile was achieved only after codon optimization which included the elimination of other expression-limiting factors such as internal ribosome entry sites, RNA secondary structures, and DNA repeats. A significant number of lipolytic genes are being discovered as part of whole genome and metagenome sequencings as revealed by the large number of putative lipolytic genes in nucleotide databanks. This study has demonstrated that codon adaptation of genes to that of heterologous host enables the expression of genes that would otherwise fail to express in a given heterologous host. This is more important in gene discovery studies based on functional activity screening, where structural genes remain inactive and therefore undiscovered as a result of the non-optimization of structural genes contained in genomic libraries transformed in heterologous hosts.

Production levels of 2298, 1091 and 750 Units/L could be achieved in $E$. coli DE3 cells for CESTs from B. pumilus, $B$. licheniformis and $G$. kaustophilus, respectively. The levels corresponded to 181,31 and $15 \mathrm{mg}$ of CESTs per litre for CESTs from B. pumilus, B. licheniformis and G. kaustophilus, respectively, calculated based on the specific activities obtained with $\rho$-nitrophenyl acetate as the substrate. A one step purification of the His-tagged recombinant CEST proteins was achieved with the use of Nickel Affinity chromatography, and this resulted in a single protein band of about $55000 \mathrm{Da}$ on SDS-PAGE gel the protein size reported for other members of Family VII lipolytic proteins [4].

The successful cloning and expression of the CESTs enabled the activity of the enzymes to be biochemically characterized. The Est95 and Est96 functioned optimally in alkaline $\mathrm{pH}$ values (7-9), had optimum temperatures of $45{ }^{\circ} \mathrm{C}$ and were thermolabile, losing more than $60 \%$ activity upon incubation for $10 \mathrm{~min}$ at temperatures above $40{ }^{\circ} \mathrm{C}$. Similar biochemical properties were reported for Family VII CESTs derived from $B$. niacini, Bacillus sp Bp.7 and Paenibacillus sp strains [25, 26, and 27]. The biochemical properties of Est179 from $G$. kaustophilus are in accordance with the properties of est55 CEST isolated from $G$. stearothemophilus with $\mathrm{pH}$ optima between 8 and 9, optimum temperature range of 30-60 ${ }^{\circ} \mathrm{C}$ and thermostable at $60{ }^{\circ} \mathrm{C}[5]$. Est95 and Est96 preferred $\rho$-NP-C3, while Est179 showed maximum activity against $\rho$-NP-C4. For Est95 and Est179, the results were corroborated by kinetic studies that revealed $\rho-\mathrm{NP}-\mathrm{C} 3$ and $\rho-\mathrm{NP}-\mathrm{C} 4$ as preferred substrates. Based on substrate profiles, Est95, Est96 and Est179 are classified as CESTs because of their preferences for short p-nitrophenyl ester substrates and lack of activity on acyl esters with n-acyl chain lengths greater than 10 .

The primary structure analyses of the three CESTs reveal that the catalytic triad consists of Ser, His and Glu sharing with acetylcholine esterase a rare use of Glu instead of Asp as the active site carboxylate [28]. Protein similarity analyses of the CESTs from mesophilic Bacillus and Geobacillus reveal significant amino acid sequence identity, an indication that they derive from a common ancestral version, but differed in biochemical properties such as thermostability probably as a result of protein evolution which is crucial for organismic adaptation and fitness [29].

A comparative analysis of the structures of CESTs from thermophilic versus the mesophilic counterparts renders possible, the investigation of thermostabilizing factors. Far-UV CD spectra for the CESTs displayed different degrees 
of ellipticity for the mesostable (Est95 and Est96) versus the thermostable enzyme (Est179), a possible indication of an increased number $\alpha$-helices in Est179. This is further supported by previous studies that have suggested that most thermostable proteins have high contents of $\alpha$-helix [30, 31, and 32].

On the other hand, the high intrinsic fluorescence intensity exhibited by Est179 indicates that Trp residues are more exposed to solvent in this thermostable CEST when compared to the mesostable counterparts. This was in agreement with the fluorescence spectrum of thermophilic esterase reported by [21]. According to [33], Trp residues may contribute to structural stability by their hydrophobicity and $\pi$-cation interactions. It is noteworthy that the 3D structure of $G$. stearothermophilus CEST, a member of Family VII lipolytic proteins is available [10]. This could facilitate protein modeling to deduce the structural basis for enhanced thermostability which is one preferred prerequisite for CEST implementation in biocatalytic processes.

\section{CONCLUSION}

CEST from mesophilic B. pumilus and B. licheniformis species and a putative CEST from G. kaustophilus HTA426 were successfully cloned, over-expressed in E. coli and purified to near homogeneity in one step purification using nickel affinity chromatography technique. The study demonstrated the significance of gene codon adaptation which enabled successful expression of the G. kaustophilus CEST gene in Escherichia coli. The adoption of gene optimization strategies could greatly facilitate the expression of genes discovered during genome and metagenome sequences that would otherwise fail to express in heterologous hosts. The CESTs were active toward short-length p-NP esters, with high stability and activity under alkaline $\mathrm{pH}$. The CEST from G. kaustophilus is a good candidate for application in biotechnology industry given its thermostability and activity in alkaline $\mathrm{pH}$. The Geobacillus stearothermophilus CEST is available as template for three-dimensional structure modelling to elucidate structure-function properties of Family VII lipolytic proteins allowing rational protein design and tailoring the enzyme for a given application.

\section{ACKNOWLEDGMENT}

The authors would like to thank Prof Heinrich Dirr (WITS University) for assistance with the spectroscopic analysis.

\section{REFERENCES}

[1] K.E. Jaeger, B.W. Dijkstra, M.T. Reetz, "Bacterial biocatalysts: molecular biology, three-dimensional structures, and biotechnological applications of lipases," Annu Rev Microbiol, vol. 53, pp. 315-351, 1999. https://doi.org/10.1146/annurev.micro.53.1.315

[2] F. Kovacic, N. Babic, U. Krauss, K.E. Jaeger, "Classification of lipolytic enzymes from bacteria," Aerobic Utilization of Hydrocarbons, Oils, and Lipids, pp. 255-289, 2019. https://doi.org/10.1007/978-3-319-50418-6_39

[3] F. Hasan, A.A. Shah, A. Hameed, "Industrial applications of microbial lipases,” Enzyme Microb. Technol, vol. 39, pp. 235-251, 2006. https://doi.org/10.1016/j.enzmictec.2005.10.016

[4] J.L. Arpigny, K.E. Jaeger, "Bacterial lipolytic enzymes: classification and properties," Biochem J, vol. 343, pp. 177-183, 1999. https://doi.org/10.1042/bj3430177
[5] H.E. Ewis, A.T. Abdelal, C.D. Lu, "Molecular cloning and characterization of two thermostable carboxyl esterases from Geobacillus stearothermophilus," Gene, vol. 329, pp. 187-95, 2004. https://doi.org/10.1016/j.gene.2003.12.029

[6] Q.U. Maqbool, S. Johri, S. Rasool, S. Riyaz-ul-Hassan, V. Verma, A. Nargotra, S. Koul, G.N. Qazi, "Molecular cloning of carboxylesterase gene and biochemical characterization of encoded protein from Bacillus subtilis (RRL BB1)," J Biotechnol, vol. 125, pp. 1-10, 2006 https://doi.org/10.1016/j.jbiotec.2006.02.018

[7] S. Kundu, D. Roy, "Structural study of carboxylesterase from hyperthermophilic bacteria Geobacillus stearothermophilus by molecular dynamics simulation," Journal of Molecular Graphics and Modelling, vol. $28(8)$, pp. $820-827,2010$ https://doi.org/10.1016/j.jmgm.2010.03.001

[8] S. Johri, S. Rasool, S., Riyaz-ul-Hassan, V. Verma, A. Nargotra, S. Koul, G.N. Qazi, "Molecular cloning of carboxylesterase gene and biochemical characterization of encoded protein from Bacillus subtilis (RRL BB1),". Journal of biotechnology, vol. 125(1), pp. 1-10, 2006. https://doi.org/10.1016/j.jbiotec.2006.02.018

[9] B. Spiller, A. Gershenson, F.H. Arnold, R.C. Stevens, "A structural view of evolutionary divergence," Proc Natl Acad Sci, vol. 96, pp. 12305-12310, 1999. https://doi.org/10.1073/pnas.96.22.12305

[10] P. Liu, H.E. Ewis, P.C. Tai, C.D. Lu, I.T. Weber, "Crystal structure of the Geobacillus stearothermophilus carboxylesterase Est55 and its activation of prodrug CPT-11," J Mol Biol, vol. 367, pp. 212-223, 2007. https://doi.org/10.1016/j.jmb.2006.12.067

[11] D.L. Ollis, E. Cheah, M. Cygler, B. Dijkstra, F. Frolow, S.M. Franken, M. Harel, S.J. Remington, I. Silman, J. Schrag J, "The alpha/beta hydrolase fold," Protein Eng, vol. 5, pp. 197-211, 1992 https://doi.org/10.1093/protein/5.3.197

[12] S. Kundu, D. Roy, "Structural study of carboxylesterase from hyperthermophilic bacteria Geobacillus stearothermophilus by molecular dynamics simulation," J Mol Graph Model, vol. 28, pp. 820-827, 2010. https://doi.org/10.1016/j.jmgm.2010.03.001

[13] R.W. Woody, "Theory of circular dichroism of proteins," In Circular dichroism and the conformational analysis of biomolecule, pp. 25-67, Springer, Boston, MA, 1996. https://doi.org/10.1007/978-1-4757-2508-7_2

[14] G. Mocz, "Intrinsic fluorescence of proteins and peptides,". cited May, $10,2002$.

[15] M.B. Nthangeni, F. Ramagoma, M.G. Tlou, D. Litthauer, "Development of a versatile cassette for directional genome walking using cassette ligation-mediated PCR and its application in the cloning of complete lipolytic genes from Bacillus species," J Microbiol Methods, vol. 61, pp. 225-234, 2005 https://doi.org/10.1016/j.mimet.2004.11.021

[16] J. Sambrook, E.F. Fritsch, T. Maniatis, Molecular cloning: a laboratory manual, 2nd ed. Cold Spring Harbor Laboratory Press, NY: Cold spring Harbor, 1989.

[17] K.J. Rashamuse, S.G. Burton, W.H. Stafford, D.A. Cowan, "Molecular characterization of a novel family VIII esterase from Burkholderia multivorans UWC10," J Mol Microbiol Biotechnol, vol. 13, pp. 181-188, 2007. https://doi.org/10.1159/000103610

[18] M.M. Bradford, "A rapid and sensitive method for the quantitation of microgram quantities of protein utilizing the principle of protein-dye binding," Anal Biochem, vol. 72, pp. 248-254, 1976. https://doi.org/10.1006/abio.1976.9999

[19] U.K. Laemmli, "Cleavage of structural proteins during the assembly of the head of bacteriophage T4," Nature, vol. 227, pp. 680-685, 1970. https://doi.org/10.1038/227680a0

[20] H. Takami, Y. Takaki, G.J. Chee, S. Nishi, S. Shimamura, H. Suzuki, S. Matsui, I. Uchiyama, "Thermoadaptation trait revealed by the genome sequence of thermophilic Geobacillus kaustophilus," Nucleic acids research, vol. 32(21), pp. 6292-6303, 2004. https://doi.org/10.1093/nar/gkh970

[21] P. Del Vecchio, G. Graziano, V. Granata, G. Barone, L. Mandrich, M. Rossi, G. Manco, "Denaturing action of urea and guanidine hydrochloride towards two thermophilic esterases," Biochemical Journal, vol. 367(3), pp.857-863, 2002. https://doi.org/10.1042/bj20020695

[22] M. Ahn, S. Kim, M. Kang, Y. Ryu, T.D. Kim, "Chaperone-like activities of $\alpha$-synuclein: $\alpha$-synuclein assists enzyme activities of esterases," 
Biochemical and biophysical research communications, vol. 346(4), pp.

1142-1149, 2006.

https://doi.org/10.1016/j.bbrc.2006.05.213

[23] A. Bielen, H. Ćetković, P.F. Long, H. Schwab, M. Abramić, D. Vujaklija, "The SGNH-hydrolase of Streptomyces coelicolor has (aryl) esterase and a true lipase activity," Biochimie, vol. 91(3), pp. 390-400, 2009. https://doi.org/10.1016/j.biochi.2008.10.018

[24] L. Whitmore, B.A. Wallace, "DICHROWEB, an online server for protein secondary structure analyses from circular dichroism spectroscopic data," Nucleic acids research, vol. 32(suppl_2), pp.W668-W673, 2004. https://doi.org/10.1093/nar/gkh371

[25] N. Prim, F.I. Pastor, P. Diaz, "Cloning and characterization of a bacterial cell-bound type B carboxylesterase from Bacillus sp. BP-7," Curr Microbiol, vol. 42, pp. 237-240, 2001. https://doi.org/10.1007/s002840110210

[26] H.K. Kim, H.S. Na, M.S. Park, T.K. Oh, T.S. Lee, "Occurrence of ofloxacin ester-hydrolyzing esterase from Bacillus niacini EM001," Journal of Molecular Catalysis B: Enzymatic, vol. 27, pp. 237-241, 2004. https://doi.org/10.1016/j.molcatb.2003.11.007

[27] J.L. Sussman, M. Harel, F. Frolow, C. Oefner, A. Goldman, L. Toker, I. Silman, "Atomic structure of acetylcholinesterase from Torpedo californica: a prototypic acetylcholine-binding protein," Science, vol. 253, pp. 872-879, 1991. https://doi.org/10.1126/science.1678899

[28] P.E. Tomatis, S.M. Fabiane, F. Simona, P. Carloni, B.J. Sutton, A.J. Vila, "Adaptive protein evolution grants organismal fitness by improving catalysis and flexibility," Proc Natl Acad Sci, 30; 105(52):20605-10, USA: Epub, 2008. https://doi.org/10.1073/pnas.0807989106

[29] F.A. Rainey, D. Fritze, E. Stackebrandt, "The phylogenetic diversity of thermophilic members of the genus Bacillus as revealed by 16S rDNA analysis," FEMS Microbiol. Lett, vol. 115, pp. 205-211, 1994. https://doi.org/10.1111/j.1574-6968.1994.tb06639.x

[30] E. Querol, J.A. Perez-Pons, A. Mozo-Villarias, "Analysis of protein conformational characteristics related to thermostability," Protein Engineering, Design and Selection, vol. 9(3), pp. 265-271, 1996. https://doi.org/10.1093/protein/9.3.265

[31] S. Kumar, C.J. Tsai, R. Nussinov, "Factors enhancing protein thermostability," Protein engineering, vol. 13(3), pp. 179-191, 2000. https://doi.org/10.1093/protein/13.3.179

[32] A. Szilágyi, P. Závodszky, "Structural differences between mesophilic, moderately thermophilic and extremely thermophilic protein subunits: results of a comprehensive survey," Structure, vol. 8(5), pp. 493-504, (2000). https://doi.org/10.1016/S0969-2126(00)00133-7

[33] D.A. Dougherty, "Cation-pi interactions in chemistry and biology: a new view of benzene, Phe, Tyr, and Trp," Science, vol. 271(5246), pp. 163, 1996.

https://doi.org/10.1126/science.271.5246.163 